\title{
Rhetorical Ambiguity, Democracy and Political Change: The Contradictions of the Hong Kong Political System
}

\author{
Ambiguedad retórica, democracia y cambio político: las \\ contradicciones del sistema político de Hong Kong
}

\author{
JENNIFER ANNE EAGLETON \\ Hong Kong Democratic Foundation, China
}

\begin{abstract}
In 1997, Hong Kong returned to China under the governance framework of «One Country, Two Systems», which was devised to allow mainland China to remain «socialist», while Hong Kong could maintain its capitalist system. However, as a rhetorical and legal strategy to maintain the metaphorical and constitutional distance between the two places yet still assert sovereignty and achieve unity, it is ambiguous and contradictory. This article examines these ambiguous contradictions (strategic, ideological and rhetorical) and then the impacts of these on Hong Kong's discussion of democracy and universal suffrage which its constitution, the Basic Law, promises in the future.

KEYWORDS

AMBIGUITY DEMOCRATIZATION, DECOLONIZATION, ELECTIONS, HONG KONG

\section{RESUMEN}

En 1997, Hong Kong volvió a China en el marco de la gobernanza conocida como «Un país, dos sistemas», que fue ideado para permitir a la China continental seguir siendo «socialista», mientras Hong Kong podía mantener su sistema capitalista. Sin embargo, la estrategia retórica y legal de mantener metafórica y constitucionalmente la distancia entre los dos lugares y seguir afirmando su soberanía y unidad, es ambigua y contradictoria. Este artículo explora estas ambiguas contradicciones (estratégicas, ideológicas y retóricas) y tras ello su impacto en el debate sobre la democracia y el sufragio en Hong Kong, que su constitución, la Ley básica, promete para el futuro.
\end{abstract}

(C) Contrastes. Revista Internacional de Filosofia. Suplemento 20 (2015), pp. 77-93. ISSN: 1136-9922 Departamento de Filosofía, Universiad de Málaga, Facultad de Filosofía y Letras

Campus de Teatinos, E-29071 Málaga (España) 


\section{PALABRAS CLAVE \\ AMBIGÜEDAD DEMOCRÁTICA, DESCOLONIZACIÓN, ELECCIONES, HONG KONG}

Unlike other British colonies, Hong Kong experienced decolonization but not independence, instead becoming a Special Administrative Region (SAR) of China with a constitution, the Basic Law, which promised full universal suffrage in the future. The «One Country, Two Systems» principle was devised to allow the socialist system to be practiced in mainland China, while Hong Kong could maintain its capitalist system. However, as a rhetorical and legal strategy to «maintain the metaphorical and constitutional distance between China and Hong Kong» (Fu et al. 2007), and to "assert sovereignty and achieve unity» (Wesley-Smith 1996, 106) it is somewhat ambiguous and contradictory.

This article first examines the historical context and content of the «One Country, Two Systems» principle, and then its ambiguity, which is strategic, ideological, and rhetorical in nature. Thirdly, it will show that the «democratic promise» written into Hong Kong's Basic Law and its intersection with the «One Country, Two Systems» principle highlights this tri-fold ambiguity. In Hong Kong's case, political expediency, the «elasticity» of the concept of democracy, and the polysemy of language, serves to show how the ideas of democracy are expanded or contracted to fit in with historical realities.

\section{HiSTORICAL REALITIES}

The annexing of Hong Kong in the mid-1800s by Great Britain was long considered a «humiliation to the Chinese people». In fact, Hong Kong had been «written into Chinese national history as a sign of humiliation» (Callaghan 2004, 212) at a time when China was neither stable nor prosperous but rather viewed as the «sick man of Asia». Hong Kong Island had been ceded to Great Britain outright under the «unequal Treaty» of Nanking (1842) but the area known as the «New Territories» located on the Mainland had later been leased to Britain for ninety-nine years (that is, till 1997). When the need to «remove the uncertainty» about the 1997 deadline arose, discussions on Hong Kong's future began.

Both Britain and China had «the common aim of maintaining the stability and prosperity of Hong Kong», according to British Prime Minister Margaret Thatcher when she met Chairman Deng Xiaoping in Beijing on 24 September 
1982 to open discussions. ${ }^{1}$ Communist China had benefited economically from free, capitalist and prosperous Hong Kong as means for contact with the outside world, and as a source of finance and trade. For Britain's part, it wanted to maintain good trading links with China and leave on good terms with the Hong Kong public.

At the start of formal negotiations, Britain «explained in detail the systems prevailing in Hong Kong and the importance for these systems of the British administrative role and link» (Sino-British Joint Declaration 1984). It tried to make the case that Hong Kong was successful and prosperous because of its difference from China, the respective (and incompatible) systems co-existing because of its colonial status, and the presence of the British running these systems. Following extensive discussion, however, it became clear that the continuation of British administration after 1997 was unacceptable to China in any form (that is, sovereignty in exchange for the right to rule). This arrangement would have implied that China was unable to govern Hong Kong satisfactorily.

However, if other «arrangements acceptable to the Hong Kong people» were found, Britain would acquiesce to China's demands for "full sovereignty». In other words, the colonial «buffer» (Wesley-Smith 1996, 106) would be removed. In its place, Britain desired to replace this «buffer» with a legally binding promise that would largely keep in place its existing systems:

[...] Examining with the Chinese how it might be possible to arrive at arrangements that would secure for Hong Kong a high degree of autonomy under Chinese sovereignty, and that would preserve the way of life in Hong Kong, together with the essentials of the present systems (Wesley-Smith 1996, 106).

Governance in Hong Kong was radically different from that of China and Deng Xiaoping remembered the principle of «One Country, Two Systems» previously formulated to entice Taiwan back into the national fold.

1 The Cultural Revolution in China had just ended in 1976-Hong Kong considered itself a haven from the extreme political campaigns next door-: «In Hong Kong, we do not want politics of any kind, neither of the left nor the right. What we need is to continue to build up our economy, to export our goods by which means alone we can give our people the jobs that they need, and bold out to them the prospects of better standards of life. We are an industrial and trading community and economic activities should command our whole interest [...]) (Official Report of Proceedings, Legislative Council, 28 June 1967, 354). 


\section{THE STRATEGIC AMBIGUITY OF «ONE COUNTRY, TWO SYSTEMS»}

The «One Country, Two Systems» was merely a general principle when it was introduced as Hong Kong's governance framework at the start of its life as a SAR of China. Being a mere principle, it provided space for future development of the concept and a «plausible deniability» (Eisenberg 1984) about what it could or could not contain. Strategic ambiguity, a concept oft used in foreign affairs and commercial organizations provides a mechanism whereby «various constituencies can claim victory» (Eisenberg 1984, 423); in the absence of a clear disconfirming message, a receiver will «attach a meaning that is congruent with his attitudes, thus assimilating the message» (Goss 1973, 166).

The main components of «One Country, Two Systems» were that Hong Kong would have «a high degree of autonomy» and that it would be «Hong Kong people ruling Hong Kong». This was laid down in the Sino-British Joint Declaration of September 1984, which set out, in twelve general principles, China's basic policies for Hong Kong. These principles were to be enacted by China in the future Basic Law, which would be supervised by the National People's Congress of China and not by Britain.

Perhaps the most important basic policy regarding Hong Kong as a «second system» of China is as follows:

(2) The Hong Kong Special Administrative Region will be directly under the authority of the Central People's Government of the People's Republic of China. The Hong Kong Special Administrative Region will enjoy a high degree of autonomy, except in foreign and defense affairs which are the responsibilities of the Central People's Government (Sino-British Joint Declaration 1984).

This «high degree of autonomy» was not defined, apart from what it does not contain: «foreign and defense affairs» which was within the purview of China. And as some commentators in the post-1997 discourse would claim, a «high degree» did not mean that Hong Kong was autonomous.

The «buffer» of achieving a quasi «status quo» post-1997 is what Britain wanted to instill confidence in Hong Kong; the mainland also wanted the territory to remain stable and prosperous but without the humiliating «colonial content» (Xiao 2001, 237). This resulted in the Declaration having four provisos on «no changes» (such as no changes to the existing social and economic systems); four on «maintenance» (such as the maintenance of its status as a free port and as a separate customs territory); and two on «continuity» (for foreign exchange, gold, securities and futures, and the Hong Kong dollar will continue 
to circulate and remain freely convertible) in the actual Joint Declaration. It annexes included ten provisos on «maintenance», nine on "preservation» and seven that the SAR can make decisions on its own on a series of issues. Furthermore, «[t]he HKSAR will be vested with executive, legislative and independent judicial power, including that of final adjudication». However, the laws currently in force in Hong Kong would remain «basically unchanged» (Paragraph 3 of Sino-British Declaration 1984). «Basically unchanged» could be taken to mean some change, of course.

The Joint Declaration was an expedient way to achieve a strategic objective of giving Hong Kong people confidence in the future, a «graceful retreat» for the British and flexibility for Hong Kong. It reiterated China's views on sovereignty and past unequal treaties as well as demonstrating China's new world status (Ghai 1999). The British thought that it had secured an honorable settlement for Hong Kong, including a guarantee of democracy (more on this later). However, «these details, intended to strengthen this autonomy, were turned into restrictions on this autonomy» (Ghai 1999, 55), because its emphasis was on systems relating to economics, law, and social policies rather than the organizations that develop them. The primary purpose of the Declaration was to keep the status quo rather than promoting further institutional autonomy which might threaten that status quo (Ghai 1999, 55).

\section{IDEOLOGICAL AMBIGUITY OF «ONE COUNTRY, TWO SYSTEMS»}

There was no precedent for two systems co-existing in the one country, so it was written into China's constitution that special administrative regions «could be established when necessary» (Article 31 of the PRC Constitution). However, «[t]he systems to be instituted in special administrative region would have to be prescribed by law «[...] in the light of the specific conditions» (Ibid). «Specific conditions» of course need specific circumstances in order to be fully fleshed out.

The «One Country, Two Systems» can be attributed to the Marxist-Leninist dogma of «dialectical and historical materialism» (Stalin 1938) as well as «seeking truth from facts» ${ }^{2}$ (that is, materialism) and the Marxist principle

2 «Seek truth from facts» was first quoted by Mao Zedong during a speech at the Sixth National Congress of the Chinese Communist Party in 1938, in reference to pragmatism; it was further promoted by Deng Xiaoping as a central ideology of socialism with Chinese characteristics, post-«Open Door» period and applied to economic and political reforms thereafter (Deng 1978). 
of the «unity of opposites» (or contradictions/dialectics). Deng Xiaoping had said: «Marxism is not a dogma but a guide to action» and that the dialectic is «evolutionary not mandatory» (2004). More colorfully, Deng called this is «black cat/white cat theory», it does not matter the color of the cat, as long as it catches mice. This is why Chinese officials like to draft agreements in general rather than more specific principles.

Within the dialectic of the «unity of opposites», the political liaison between Hong Kong and Beijing is dynamic but not equal. The center manipulates the «actual situation» of the periphery in perpetual tension, thus Deng's saying of «crossing the river by feeling the stones». Thus, the principles underlying the concept of «One Country, Two Systems» could be subject to constant change (in the light of actual conditions on the ground). And since it was constantly reiterated that the "One Country» was the premise for the "Two Systems», there is an implication that the «One Country» could take precedence over the «Two Systems». As one pro-Beijing Hong Kong newspaper put it, «if there is no 'One Country' then there cannot be 'Two Systems'» (Staff Reporter 2004, A03). This became a prominent refrain when discussing Hong Kong's future democratization, since article 3 of the Chinese Constitution states:

Article 3: The state organs of the People's Republic of China apply the principle of democratic centralism. The National People's Congress and the local people's congresses at different levels are instituted through democratic election (italics added) (PRC Constitution).

There are several official «democratic parties» on the mainland, but they are under the umbrella of the Chinese Communist Party and acknowledge the latter's leadership.

\section{RHETORICAL AMBIGUITY: THE UNDEFINED PROMISE OF DEMOCRACY}

One significant aspect of the negotiations on Hong Kong's future was the last-minute insertion of the word «elections» into the Joint Declaration, five days before the draft agreement was initialed (Cottrell 1993, 17). This is also a part of the overall strategic ambiguity and used to build up confidence that Hong Kong would continue on in similar ways to before.

The British usually made steps to institute democracy on exiting its colonies. Some saw this as a means to build up a class of political leaders who spoke the same «language» (i.e., ideology) as themselves. The old colonial 
power might then retain some influence over the leaders of their ex-colonies. However, in Hong Kong's case, its «special circumstances» affected the usual decolonization experience and fear of economic downturn, instability under an «ideological» China, conflicted with what some saw their «moral obligation» of introducing some form of self-government. This ambivalence can be illustrated in the various documents relating to Hong Kong's political development during the 1980s which will be shown in the following section.

The insertion of the word «elections» in the Joint Declaration signaled Hong Kong's future «democratic road» by providing that the Chief Executive would be selected «on the basis of the results of elections or consultations held locally» (written into in the Joint Declaration itself and Annex I) and that the «legislature [...] shall be constituted by elections» (written in Annex I of the Declaration only). No timetable was included for these elections nor was the term «elections» defined.

«Elections» can mean quite different things. From past government reports and consultation documents, the British obviously considered that «elections» need not mean multiparty universal suffrage and that it could include either direct or indirect elections. While to ordinary people, familiar with Western systems as a colony, they were likely to mean ballots where their votes had equal weight and why anybody could stand and be elected to office. To the Mainland Chinese, however, the word «election» (vote/select/elect) did not mean «universal suffrage». Elections in China under the communist system are more like «consultations». Elections for Chinese Communist Party (CCP) bodies are «selections» where the candidates are pre-selected or approved by the party hierarchy in numbers equal or almost equal to the posts available. Since all the candidates are acceptable to the party an election can then take place (Loh 2010, 160-162).

Despite accuracy and precision being a perceived characteristic of legal language, in international relations, linguistic ambiguity or vagueness may be consciously used in certain negotiating situations (Mattila 2006, 65) as shown in Hong Kong's case. Because discussion of the introduction of a form of democracy in Hong Kong was the cause of much fractious debate between the two sides, leaving the word «elections» undefined and unexplained meant that this left room for later discussion without endangering the Joint Declaration coming into force. Since the two sides reached a consensus over economics and financial matters generally, negotiators allowed the insertion of ambiguous terms in the treaty so that the problems were left to be solved later, in this case in the drafting of the Basic Law, which would be handled by China alone, albeit with some input by British and Hong Kong representatives on the Basic Law Drafting Committee. 
Debates in the British and Hong Kong governments involved people arguing for greater representative government in Hong Kong saying it was a necessary structure for the high degree of autonomy while others providing «good reasons» for not pursuing democratic reform as they would have liked. For example, while acknowledging that many in Hong Kong were mature enough for direct elections and frustrated with the lack of political representation, British parliamentarian George Walden said that the «[...] the very absence of democracy has been one of the features for continuity in Hong Kong. It is one of the reasons why the Chinese have not moved against it or been tempted to intervene» (Hansard, 16 May 1984). The reason for its success in other words was that it had not practice democracy during its history.

Walden also went on to say «it would be wrong to get carried away to encourage people to believe that what we regard as normal democratic institutions and party politics can have much of a future in Hong Kong» (Hansard, 16 May 1984). He and other government officials gave similar reasons. ${ }^{3}$ First, it would arouse Chinese suspicions and affect negotiations as well as the interim period to 1997; second, if they went too far and too quick in democratization «we would stir up commotion and conflict and later political passions»; and third, even if further democratization was to take place, it would not necessarily create a «Western-type democracy», since political parties which would create difficulties with communist China (Hansard, 16 May 1984).

It is also interesting to note in the Joint Declaration that the Chief Executive «will be appointed [...] on the basis of the results of elections or consultations held locally» (Article 3, Item 4 of the Joint Declaration), giving the option of either an election or a consultation. Furthermore, the Joint Declaration states that, in addition to being elected or selected (through consultation), he or she would be «appointed by the Central People's Government». If someone could be so «appointed», it follows that they can then be «un-appointed». This is another key example of linguistic differentiation.

\section{IV.1 RHETORICAL AMBIGUITY CONTINUED: DRAFTING THE BASIC LAW}

The fundamental laws of states are usually «modeled» (Elkins, Ginsburg and Melton 2005), after countries that are similar to theirs (such as size, ethnolinguistic fragmentation, or security environment), reasoning that what is good for similar state would also be good for them. However, it was said of Hong

3 Many such discussions can be gleaned from the United Kingdom Parliamentary discussions and they can be found at: http://hansard.millbanksystems.com/sittings/1980s. 
Kong, «in terms of its form, the political system is not entirely occidental nor is it completely oriental» (Rao and Wang 2007, 341). Therefore the drafting of the Basic Law could not mimic either of those systems. According to paramount Chinese leader Deng Xiaoping, it had to delineate the boundaries between national sovereignty and local autonomy; comply with the Joint Declaration; preserve and improve the existing system while removing the «colonial elements»; it also had to be in compliance with the principles of democracy and take consideration of different sectors.

The first draft of the Basic Law was released in April 1988 and the lack of agreement on a future political system was reflected in its multiple options for selection of the Chief Executive and the Legislative Council. This reflected the two major groups in the drafting/consultative committees as mentioned earlier (one conservative and one liberal) reflected their ideological stance of the former balancing direct elections with indirect elections involving specialized electorates while the more liberal group urged universal suffrage for the Chief Executive. However, even the liberal group still did not advocate a wholly indirectly elected legislature. ${ }^{4}$

\section{IV.2 TIANANMEN SQUARE AND ITS (RHETORICAL) EFFECT ON HONG KONG'S FUTURE DEMOCRATIZATION}

While the last Basic Law draft was distributed for public comment in 1989, the Tiananmen crackdown on 4 June 1989 changed Hong Kong and altered how Beijing considered Hong Kong; it also transformed Britain's attitude, and marked a turning point in Hong Kong's people's views on representative government; there were calls for faster democratization, some seeing the incident as highlighting the «importance of One Country, Two Systems» and the need to firm up Hong Kong's «high degree of autonomy», otherwise it could be «Today's Beijing, Tomorrow's Hong Kong» (Loh 2010, 168). Faster democratization was necessary to retain confidence in Hong Kong many said, and it was thought a specific timetable was necessary in order to shore up confidence.

In the British Parliament, there was a tone of «sympathy» for Hong Kong's plight, and as Lord Glenarthur put it, being a captive of «[...] its history and

4 It is difficult to fully detail the negotiations over the Basic Law, a process that took from 1984 to 1990 to come to completion. And, like the Joint Declaration, the wording (according to Deng Xiaoping and Ji Pengfei, head of the Hong Kong Liaison Office) was supposed to be «loose and not too tight», as being «too tight» would «bind the future SAR's hands and feet» and if it was «broad, that is broad-brush, leaves a little space [...] then there is some flexibility if the actual situation needs it» (Tsao 2004, E18). 
geography» (Hansard, 5 July 1989). On one hand, some urged faster democratization for Hong Kong, and others like Secretary of State for Foreign and Commonwealth Affairs Geoffrey Howe were also concerned that the people of Hong Kong had to «secure the least possible damage to their economic vitality as a result of what has happened in China, because China is their largest trading partner» (Hansard, 5 July 1989); others thought it ironic that Britain was pushing for democracy in places where they had no responsibility and not pushing for it where they had responsibility: «If we are in favour of democracy in Eastern Europe and crave it for South Africa, why is it not also appropriate for Hong Kong?» (Hansard, 1 May 1990). ${ }^{5}$

\section{AMBiguous DEMOCRATIC PROMISES IN THE BASIC LAW}

Article 48 of the final version of the Basic Law reflects the lack of clarity in the promise of the shape and timing that universal suffrage would occur in Hong Kong (the earliest time that this could be done was in 2007):

The method for selecting the Chief Executive shall be specified in the light of the actual situation in the Hong Kong Special Administrative Region and in accordance with the principle of gradual and orderly progress. The ultimate aim is the selection of the Chief Executive by universal suffrage upon nomination by a broadly representative nominating committee in accordance with democratic procedures (italics added, Basic Law 1990).

A similar provision was made for the election of the Legislative Council. The following sections discuss the meaning of a few of these contested

5 Some other British Parliamentary Hansard excerpts: «Is not the best guarantee for Hong Kong people not to clamour to get out of Hong Kong, but rather to stay in Hong Kong, to develop and entrench their democracy, and to make Hong Kong the success that it undoubtedly can be? That success is the best guarantee, and the only long-term guarantee, of Hong Kong's future» (Hansard, 1 March 1990).

The Secretary of State for Foreign and Commonwealth Affairs Mr. Douglas Hurd: «I think that my right hon. Friend is right. The events of last June have both increased the appetite and feeling in Hong Kong in favour of democracy and made the Chinese Government defensive, and, to use my right hon. Friend's word, 'difficult'. Our job is to continue to try to persuade the Chinese Government that Hong Kong's future in China -two systems, one country-depends, if it is to be successful, on keeping alive the spirit of enterprise and freedom in the territory. This measure is part of that. It is a start to democracy, not, as some headlines in today's press suggest, an end to it. It is a more substantial start than was envisaged previously» (Hansard, 16 February 1990). 
phrases: «universal suffrage», «actual situation», and «gradual and orderly progress», which served to frame the future discourse of Hong Kong's future democratization.

\section{V.1 UnIVERSAL SUFFRAGE}

According to the Oxford English Dictionary, universal suffrage consists of the extension of the right to vote to all adults:

Universal suffrage $\mathrm{n}$. (a) general agreement or consent (obs.); (b) the right of all people (formerly, all men) over a certain age in a particular nation, etc., to vote in its political elections (Oxford English Dictionary Online 2014).

«Universal suffrage» and «democratic procedures» are defined nowhere in the Basic Law (although later government papers explore the concept).

The concept of democracy as set out in the «One Country» (China) and the «Second System» (Hong Kong) are quite different. China practices «socialist democracy» or «democratic centralism» under one-party rule. Hong Kong, like the West generally, considers a «democratic system» as one possessing the rule of law, equal and fair elections, pluralism of political parties, and freedom of speech, among other enshrined principles.

Universal suffrage, like democracy, is an «essentially contested concept» (Gallie 1956; Gray 1977, 344), since it is a term that exhibits polysemy, a state which «characterizes the language of ideology»; essentially contested concepts involve widespread agreement on a concept (e.g., «fairness») but not the best realization thereof this concept. Essentially contested concepts are «concepts the proper use of which inevitably involves endless disputes about their proper uses on the part of their users», and these disputes «cannot be settled by appeal to empirical evidence, linguistic usage, or the canons of logic alone» (Gray 1977, 344). Robert A. Dahl, a noted political scientist states: «yet a term that means anything means nothing. And so it has become with 'democracy' which is not so much a term of restricted meaning as a vague endorsement of a popular idea» (Dahl 1989, 2). Perhaps also part of the problem here is that when democracy is discussed, people are thinking of different things, for as Dahl $(1998,6)$ says «[...] the simple fact that 'democracy' refers both to an ideal and an actuality». Therefore what designates «democratic procedures» could be very broad indeed.

In Hong Kong post-1997 political discourse, «universal suffrage» was continually being (re)defined. One consultation document, referred the United Nations publication «Human Rights and Elections, A Handbook on the Legal, 
Technical and Human Rights Aspects of Elections» (United Nations 1994) in which was said that «no single political system or electoral methodology is appropriate for all people's and states» and that «each jurisdiction will ultimately be shaped by the particular needs, aspirations and historical realities of the people involved» (Paragraph 17 of the Handbook, 3). Using this to say that the United Nations has not clearly defined «universal and equal suffrage» and that no one electoral system «suits all places» and that a place's «particular needs» and «aspirations» as well as the «uniqueness of its socio-economic situation» and its «historical realities» should be taken into account, i.e., the lowering of expectations about what can be achieved under Chinese sovereignty.

\section{2 «ACTUAL SITUATION» AND «GRADUAL AND ORDERLY PROGRESS»}

«Actual situation» and «gradual and orderly progress» in articles 45 and 68 of the Basic Law could be seen as parallel principles and accorded the same level of importance. However since the «actual situation» principle precedes the "gradual and orderly progress» principle in the text, so therefore the speed of constitutional developments depends upon the «actual situation», which of course can change and be defined as necessary. «Maturity» for universal suffrage would be achieved once these various prerequisites were met. Reformulations such as these are subjective and hard to prove (i.e., when they would be achieved). Since such statements are vague, «interpretation is necessary to 'complete' the Basic Law, to explicate its reach and parameters» (Ghai 1999, 191). Thus the definition of these aspects belonged to the discourse's «gatekeepers», Beijing officials and the Hong Kong Government.

Despite the provisos that Hong Kong had a «high degree of autonomy» and that «Hong Kong people would rule Hong Kong» apart from defense and matters of foreign affairs and defense as mentioned earlier, the mainland considered that, as its constitutional development impacted on issues of Chinese sovereignty, Xiao Weiyuan and Xia Yong «guardians of the Basic Law» (as they were known) visited Hong Kong in January 2004. On their visit, they defined the meaning of «ultimate aim», «gradual and orderly progress» in the Basic Law and the primary role that Beijing had in determining Hong Kong's democratic future. Regarding attainment of the «ultimate aim», Xiao discussed the word «ultimate», literally «to finally reach the end») in the Basic Law:

First of all, «up to/reaching», universal suffrage is certainly the future of Hong Kong's constitutional development $[\ldots]$ the goal will not change, and must be achieved, and it will be achieved (Kwan 2004, AO7). 
However, before the «up to/to reach» there is still the word «final/ultimate/ eventual». In other words, the «up to/to reach» needs a process. And as long as people are somewhat accomplished in Chinese, they should understand that «eventually» is not a short process, but a relatively long, relatively late process, or why did it say «ultimate»?

Specifically, taking «50 years no change» (Article 5 of the Basic Law) as a precondition, if ten years after reunification you immediately implement universal suffrage, it would not be called «ultimate». Therefore, the «ultimate» time for universal suffrage should not be in 2007 that is obviously clear (Kwan 2004, AO7; Eu 2004, B14).

Another legal «guardian», Xia Yong, also pointed out that Hong Kong's political reform could not be too fast, or «haste brings no success», and must be based on the actual situation and gradual and orderly progress. He said: «[u]niversal suffrage is a very easy, simple thing, but you have to imagine what the consequences of universal suffrage? Can universal suffrage able to guarantee the election of someone better than Mr. Tung?» (Li 2004, E15) (Tung Chee-hwa Chief Executive was the head of the Hong Kong Government). This quote encapsulates some of the basic arguments about universal suffrage from the pro-Beijing/establishment camp; that one could not be sure of the «quality» of leader elected under such a system and the potential for instability would be great (fast democratization is equivalent to a decline in stability and prosperity). That is why many considered indirect elections a way to «weed out» radicals and functional constituencies (e.g., the real estate sector would elect a candidate out of their own ranks to serve in the Legislative Council).

After much acrimonious discussion about governance and political reform, the Hong Kong government launched its first consultation in 2004 concerning constitutional for changes that could be made in 2007/2008. The National People's Congress Standing Committee exercised its right to interpret the Basic Law and set the procedure for changing the city's electoral methods. In addition to the Basic Law principles of «the actual situation» and "gradual and orderly progress», a principle not actually stated in the Basic Law, that of «balanced participation» (meaning that different professional sectors should be voted in by trade-based constituencies) also had to be followed. Thus the «rules of the game» changed (Daly 2004, E07). Later more factors were added that had to be considered before universal suffrage could be achieved. This was so that the pace of political development in Hong Kong should not be «too fast» and «progress should be made in a gradual and orderly manner, step by step» (Hong Kong Government 2007, 45) and through consensus. 
The Standing Committee of the National People's Congress has deemed Hong Kong ready to have universal suffrage for its Chief Executive in 2017 and followed by the legislature four years later. A consultation is currently being held with the final form of this universal suffrage hopefully clearer by the end of 2014. Likely to remain in dispute is what just universal suffrage means.

\section{CONCLUSION}

As Wittgenstein in his Philosophical Investigations (1968, 33-34) argues, problems with boundaries arise only if boundaries/borders are the major areas of concern. Ambiguous demarcation of borders leads to intractable border disputes between nations as history frequently attests. Such is the case with Hong Kong under the «One Country, Two Systems». Since other autonomous regions usually had many similarities to the «host» nation (for example, a similar governance framework), and differed only by language or some other minor cultural difference, Hong Kong is an unique case that raises questions on how two quite different systems can acquiesce together.

In 1989, Jiang Zemin famously quoted a literary saying, «the well water [Hong Kong] does not interfere with the river water [China]» to explain that Hong Kong should not interfere in China and that China would also not interfere in Hong Kong. Variations on the «well water» and «river water» theme have been used frequently throughout the discourse of Hong Kong's future democratization.

The governance framework for China and for Hong Kong from the mainland point of view, as mentioned previously has been described as «crossing the river by feeling the stones» and doing so «step by step». There has also been a contradiction between separateness -Hong Kong should not interfere in the democratic (ideological) development in China but have a mutuality of cultural and economic interchange-. However, the ultimate authority of the «river water» (being the premise for the «Two Systems») and the changing roles/ identities between the two places as the «one country» reforms economically and becomes a world power means that this separateness is blurring.

One essence of the «One country, Two Systems» is «river water not interfering with well water», which means mainland China not intervening in affairs within the scope of Hong Kong's self-autonomy. Similarly, HKSAR should not intervene in China's affairs. "One Country, Two Systems» mainly and precisely refers to the social and political systems. In the economic, cultural and livelihood perspectives, «two systems» is not some insurmountable 
«moat», but ensures mutual contact, complement in advantages and common development. All these years since the handover have already proven this point (Kwan 2006, A11).

\section{REFERENCES}

BASIC LAW. 1990: The Basic Law of the Hong Kong Special Administrative Region of the People's Republic of China. http://www.basiclaw.gov.hk/en/ basiclawtext/index.html.

CALLAHAN, W. A. 2004: «National Insecurities: Humiliation, Salvation, and Chinese Nationalism». Alternatives 29: 199-18.

COTTRELL, 1993: The End of Hong Kong: The Secret Diplomacy of Imperial Retreat. London: John Murray.

DAHL, R. 1989: Democracy and Its Critics. New Haven and London: Yale University Press.

DALY, M. 2004: «Hong Kong Enters the Totalitarian Era». Apple Daily, 14 May, EO 7. (In Chinese).

DENG, X. 1978: «Emancipate the Mind, See Truth from Facts and Unite as One in Looking to the Future». Speech given at the closing session of the Central Working Conference to prepare for the Third Plenary Session of the Eleventh Central Committee of the Chinese Communist Party, 13 December. http://english.peopledaily.com.cn/dengxp/vol2/text/b1260.html.

DENG, X. 2004: Deng Xiaoping on «One Country, Two Systems». Hong Kong: Joint Publishing.

EISENBERG, E. M. 1984: «Ambiguity as Strategy in Organizational Communication». Communication Monographs 51:227-42.

ELKINS, Z. G. T. and J. Melton. 2005: «Formal Characteristics of National

Constitutions». www.comparativeconstitutionsproject.org/theoreticalmotivations.htm

EU, A. 2004: « 'Ultimate' is a Target, Not a Time». Ming Pao Daily, 27 January, B14.

FUE et al., eds. 2007: Interpreting Hong Kong's Basic Law: The Struggle for Coherence. New York: Palgrave Macmillan.

GALLIE, W. B. 1956: «Essentially Contested Concepts». Proceedings of the Aristotelian Society 56: 167-98.

GHAI, Y. 1999: Hong Kong's New Constitutional Order: The Resumption of Chinese Sovereignty and the Basic Law. Hong Kong: Hong Kong University Press. 
GOSS, B., and L. Williams. 1973: «The Effects of Equivocation on Perceived Source Credibility». Central States Speech Journal 24: 162-67.

GRAY, J. N. 1977: «On the Contestability of Social and Political Concepts». Political Theory 5 (3): 331-48.

HANSARD's PARLIAMENTARY DEBATES: http://hansard.millbanksystems. $\mathrm{com} /$.

HONG KING GOVERNMENT. 2007: Green Paper on Constitutional Development. www.cmab.gov.hk/doc/issues/GPCD-e.pdf.

KWAN, C. 2004: «'Ultimate'...2047 for Universal Suffrage?». Ta Kung Pao, 19 January, AO7. (In Chinese).

KWAN, C. 2006: «Is Anson Chan's 'Reform Trial' An Affront to the Hong Kong People?». Ta Kung Pao, 15 July, A11. (In Chinese).

LEGISLATIVE COUNCIL OF HONG KONG. 1967: Official Report of Proceedings. 28 June, 354. http://www.legco.gov.hk/1967/h670628.pdf.

LI, Y: 2004. «Articles Show Where the Central Government Will 'Do Something'». Apple Daily, 17 January, E15. (In Chinese).

LOH, C. 2010: Underground Front: The Chinese Communist Party in Hong Kong. Hong Kong: Hong Kong University Press.

MATTILA, H. 2006: Comparative Legal Linguistics. Hampshire: Ashgate.

Oxford English Dictionary Online. 2014. «Universal». Oxford University Press. http://www.oed.com/view/Entry/214783?redirectedFrom=univers al+suffrage.

PRC. 2004: Constitution of the People's Republic of China. http://english.gov. $\mathrm{cn} / 2005-08 / 05 /$ content 20813.htm.

RAO, G. and Z. Wang. 2007: «Hong Kong's One Country, Two Systems' Experience under the Basic Law: Two Perspectives from Chinese Legal Scholars». Journal of Contemporary China 16 (52): 341-358.

SINO-BRITISH JOINT DECLARATION. 1984: Full Title: «Draft Agreement between the Government of the United Kingdom of Great Britain and Northern Ireland and the Government of the People's Republic of China on the future of Hong Kong». http://archive.org/stream/draftagreementbe 00hong/draftagreementbe00hong_djvu.txt.

STAFF REPORTER. 2004: «Ng Leung Sing and Leung Fu Wah: If There is no 'One Country', There can be no 'Two Systems'». Ta Kung Pao, 11 February, AO3. (In Chinese).

STALIN, J. 1938: Dialectical and Historical Materialism (a pamphlet). http:// www.marxists.org/reference/archive/stalin/works/1938/09.htm.

TSAO, C. 2004: «Saliva Bubbles». The Apple Daily, 19 January, E18. (In Chinese). 
UNITED NATIONS. 1994: Human Rights and Elections, A Handbook on the Legal, Technical and Human Rights Aspects of Elections. www.ohchr.org/ Documents/Publications/training2en.pdf.

WESLE-SMITH, P. 1996: «Law in Hong Kong and China: The Meshing of Systems». Annals of the American Academy of Political and Social Science 547: 104-117. http://archive.org/stream/draftagreementbe00hong/ draftagreementbe00hong_djvu.t

WITTGENSTEIN, L. 1968: Philosophical Investigations, translated by G.E.M. Anscombe. Oxford: Blackwell.

XIAO, W. 2001: One Country, Two Systems: An Account of the Drafting of the Hong Kong Basic Law. Beijing: Peking University Press. 
